\title{
Hedonic Analysis of the Impact of Flood Events on Residential Property Values in Malaysia: A Study of Willingness to Pay
}

\author{
Nur Hafizah Ismail \\ Mohd Zaini Abd Karim ${ }^{b}$ \\ Bakti Hasan-Basric \\ Universiti Utara Malaysia
}

\begin{abstract}
The effect of flooding on residential property values (RPV) is a major concern to all property buyers and owners. Although numerous studies have already discussed the risk of devaluation of those properties situated in flood prone areas, those that focused on the impact of flooding on residential properties in Malaysia are still limited. This paper extends existing literature by also estimating consumers' willingness to pay for flood control measures to reduce the flood risk in Malaysia. Using the hedonic pricing model (HPM), our results suggest that the market value of urban and rural residential properties significantly decreases by 18.5 percent and 13.6 percent due to flooding, respectively. The result also shows that, respondents who are risk averse are willing to pay 35.4 percent more for flood control measures to reduce impact of flood risk compared to those who are risk takers. The results of this study can help property owners to understand the factors that contribute to property devaluation due to flooding. This study also proposes flood insurance programmes to be implemented as flooding is a major concern to real property owners.
\end{abstract}

Keywords: Floods, hedonic price model, property, valuation JEL classification: Q54, R21, R32

\section{Introduction}

Flood is a natural phenomenon that can have disastrous effect on the environment and on those affected communities (IFRC, 2009; Jha, Bloch, \& Lamond 2012). It is also one of the most frequent and most costly due to the damages it can cause to properties, livelihoods and human health. In terms of asset loss, flooding can destroy public infrastructures, houses and other real and personal properties. The destruction that floods bring disrupts people's daily lives, with some even forced to leave their homes.

a School of Economics, Finance and Banking, Universiti Utara Malaysia, 06010 Sintok, Kedah, Malaysia. Email: hafizah19@live.com, n.hafizah.mohammad@uum.edu.my (Corresponding author)

b Othman Yeop Abdullah Graduate School of Business, Universiti Utara Malaysia, 06010 Sintok, Kedah, Malaysia. Email: zaini500@uum.edu.my

c School of Economics, Finance and Banking, Universiti Utara Malaysia, 06010 Sintok, Kedah, Malaysia. Email: bakti@uum.edu.my

* The authors wish to thank the Ministry of Higher Education Malaysia for funding this study under the Long-Term Research Grant Scheme (Code LRGS/b-u/2012/UUM/Teknologi Komunikasi dan Informasi). The views expressed in this study are those of the authors and do not necessarily reflect the views or policies of the ministry or the project team. Any errors are the sole responsibility of the authors. 
The extent of damage that floods bring to communities and properties vary; it depends on the characteristics of the flood that hits the community, such as the location, duration, depth and velocity of the flood (Queensland Flood Science, Engineering and Technology Panel, 2012). Recovery period of the affected communities also depends on the type of flood that affected them. If a community experiences minor flooding, then recovery would be fairly quick. However, if a community is devastated by a major flooding, then it would take a longer time to recover; recovery and repair of damaged properties would also be very expensive and slow (Nicholas, Holt, \& Proverbs, 2001; Soentato \& Proverbs, 2004), and can result in depreciation of asset values (Eves, 2002; Hughes, 2000; Tobin \& Montz, 1994).

The impacts of flooding on properties have often been analysed through residential property value (RPV) and land property value (Babcok \& Mitchell, 1980; Bin \& Polasky, 2004; Saptutyningsih \& Suryanto, 2011; Zhai, Fukuzono, \& Ikeda, 2003). The studies that have determined the impacts of flooding on RPV in developed countries have generally shown that flooding reduces RPVs (Bin \& Kruse, 2006; Eves, 2002; Troy \& Romm, 2004), although some have shown otherwise. Babcock and Mitchell (1980) found that flooding has no significant impact on RPV, whereas Tobin and Montz (1990) found a slight increase in the prices of residential properties in flood prone areas. Based on these contrasting results, it can be said that flooding has varying impacts on RPV; this variation may be due to the nature of flood, such as flood depth, flood duration and flood frequency (Eves, 2004; Fridgen \& Shultz, 1999; Lambley \& Cordery, 1991).

Malaysia suffers from frequent flooding every year, with most of its areas getting flooded during the periodic monsoon seasons. Although the flooding situation in Malaysia is not as serious as in other countries, the annual flooding still affects the Malaysian population due to the damages it causes to properties. The effect of floods on properties has become one of the common concerns of households in both urban and rural areas. Generally, all urban houses in Peninsular Malaysia are fully made from bricks (permanent), while many rural houses are made from wood or wood and bricks (semi-permanent). The price of concrete-brick urban houses is higher than the traditional semi-permanent houses in the rural areas, as the structure of urban houses are stronger and more durable. Therefore, the occurrence of a flood event might have a different effect on property values in the urban and rural areas.

There are only a handful of studies that have been conducted on flood in Malaysia which focussed on flood hazards and disaster risk reduction and management. For example, Chan (1996) and Rahman (2012) focussed on the citizen's level of understanding of flood risks and hazards and the policy regulations practised by the Malaysian government to address these concerns. Studies by Chan (1997) and Khalid and Shafiai (2015) examined the causes of flooding while Singh and Subramaniam (2009) explored the country's preparedness against health risks imposed by flood events. Although Beksin (2011), Ismail, Karim and Hasan-Basri (2014), and Ismail, Karim and Hasan-Basri (2016) investigated the effect of flooding on property values in Malaysia, their studies did not analyse consumers' willingness to pay for flood control measures.

Literature on the hedonic pricing model (HPM) and its application to property research in Malaysia is also very limited (e.g., Keng, 2008; Mar Iman, Hamidi, \& Liew, 2009; Othman, Othman, \& Mohd Noor, 2006) and only a few studies incorporate flood 
as a factor (Beksin, 2011; Ismail, Karim, \& Hasan-Basri, 2014; Ismail, Karim, \& HasanBasri, 2016). Hence, this research area is largely unexplored, which makes investigating the differences in the effects of flooding on the RPV in Malaysia and consumers' willingness to pay for flood control measures a noteworthy endeavour.

This paper aims to: (1) determine the effects of flooding, as measured by flood frequency, on RPV in urban and rural areas in Malaysia, and (2) to determine Malaysian consumers' willingness to pay for flood control measures to reduce the impact of flood risk. This study can help to inform policy makers in the efficient design and allocation of property development projects in order to ensure that losses will be minimised in cases of flooding.

This study contributes to the body of literature on the estimation of RPV in Malaysia by extending the study to include the measurement of willingness to pay for flood mitigation measures to reduce flood risk. This study differs significantly from previous similar studies on flood and property values in Malaysia done by Ismail, Karim and Hasan-Basri (2014) and Ismail, Karim and Hasan-Basri (2016) in several ways. First, the flood indicator used in this study, flood frequency, differs from the previous study done by Ismail, Karim and Hasan-Basri (2014). Second, this study extends the work of Ismail, Karim and Hasan-Basri (2014) by including the second stage HPM regression in the analysis. Third, this study analyses the effect of flood on residential property values in the urban and rural areas separately.

The remainder of the paper is organised as follows. Section 2 reviews the related literature on the effect of flooding on RPV. Section 3 explains the methodology applied in the study. Section 4 provides the empirical results and discussion. Finally, Section 5 presents the conclusion and recommendations of the study.

\section{Review of Related Literature}

The impact of flooding on RPV can be measured through flood depth, duration and frequency (Eves, 2004; Handmer \& Smith, 1990; Soentato \& Proverbs, 2004). Handmer and Smith (1990) and Minnery and Smith (1996) suggested that flood depth significantly impacts the extent of property damage; therefore, the same factor can also affect property value. For example, minor flooding causes little damage to properties; however, if the floodwater rises above the floor level, it can cause considerable damage to houses, which can affect property values in the flooded area. Meanwhile, Eves (2004) and Soentato and Proverbs (2004) found a negative correlation between flood duration and residential property value. In general, the longer the duration of the flooding, the greater the amount needed to repair the damaged property, which results in a reduction in property value.

However, most of the existing literature show that flood frequency is an important variable in estimating the impact of flooding on RPV (Eves, 2004; Shultz \& Frigden, 2001). Sheaffer and Greenberg (1981) and Shrubsole and Scherer (1996) showed that the more frequent that flooding occurs, the greater is its impact on residential property prices. Eves, Blake and Bryant (2010) demonstrated that flood frequency has more influence on market prices of properties compared to other measurements such as flood depth and flood duration. 
A few studies have cited that flood frequency has no relationship with RPV. PRC (1992) recorded that property prices had not declined in Sydney even after a second flooding in 1988 happened in the city. Speyrer and Ragas (1991) also found that repeated flooding had no effect on property values in New Orleans. According to Lamond and Proverbs (2006), this seeming unresponsiveness of property prices to flooding may be due to the price inflation of residential properties. Babcock and Mitchell (1980) also cited that a low perception of flood risk in the residential area may explain why flood frequency has no significant impact on property value.

On the other hand, many studies have shown that flood frequency affects residential property values. Tobin and Montz (1990) found that prices of residential properties that had been flooded slightly increased; this may due to the value-added from house repairs and renovation after the flood event. Conversely, Eves (2004) found that an increase in flood frequency reduced the sale price and value of houses in areas where flooding had occurred. Similarly, Montz (1992a, 1992b) discovered that the second flooding in Thames, New Zealand in 1985 had significantly reduced RPVs in the area. The author also found that the values of those properties that had been flooded twice decreased; recovery of market prices of such properties had been likewise slow. Generally, properties that have been flooded numerous times tend to increase the perceived risk that it will be flooded again in the future. As a result, RPV significantly decline due to flood occurrences.

HPM is frequently used to analyse the effect of flooding on property values. This method has been applied extensively in the United States, Europe and Australia. Triplett (2004) opined that HPM is a comprehensive and practical approach. The primary advantage of HPM is that all available sales data can be used. HPM investigates the relationship between sale price and property characteristics. Ridker and Henning (1967) are among the earliest researchers who used HPM to determine house price by investigating the relationship between air pollution and property values. Later, Rosen (1974) and Freeman (1979) established the approach by estimating RPV based on the convenience that the property provides, as reflected in its structural attributes.

The results of previous studies suggest that HPM is the best method for estimating house values (Clapham, Englund, Quigley, \& Redfearn, 2004; Francke, Vos, \& Janssen 2000). Generally, HPM is widely used to study the relationship between property attributes and property values as shown in Table 1.

Generally, HPM is used to determine the relationship between property attributes and sale price. In this sense, HPM can also be used to study the effect of flooding on property values (Bin \& Polasky, 2004; Samarasinghe \& Sharp, 2010; Troy \& Romm, 2004). Although the elements of both types of studies differ as the latter involves the presence of a flood variable, they are similar since both can use the same property attributes (i.e., location, structure, neighbourhood and environment) to determine the value of a property. Previous studies have shown that HPM can be used to measure the effect of flooding on RPV (Bin \& Kruse, 2006; Harrison, Smersh, \& Schwartz, 2001; Pope, 2008).

A consumer's willingness to pay is important in welfare analysis. Rosen's (1974) hedonic model to estimate the willingness to pay is a dual way to describe equilibrium in a market with differentiated goods. He showed that a consumer choosing to buy 
Table 1. Example of previous studies on hedonic pricing model

\begin{tabular}{l|l|l}
\hline Property Attributes & Elements & Authors \\
\hline Location & $\begin{array}{l}\text { Distance to city center } \\
\text { Accessibility to transportation }\end{array}$ & $\begin{array}{l}\text { Tang (1975) } \\
\text { Sirpal (1994); Meen (2001); Des Rosiers, } \\
\text { Lagana, Theriault, \& Beaudoin (1996) }\end{array}$ \\
\hline Structure & $\begin{array}{l}\text { Number of bedrooms } \\
\text { Number of bathrooms } \\
\text { House age } \\
\text { Presence of garden }\end{array}$ & $\begin{array}{l}\text { Kain and Quigley (1970) } \\
\text { Rodriguez \& Sirmans (1994) } \\
\text { Carroll, Clauretie, \& Jensen (1996) } \\
\text { Clark \& Herrin (2000) } \\
\text { Fletcher, Gallimore, \& Mangan (2000) } \\
\text { Chau, Ma, \& Ho (2001) }\end{array}$ \\
\hline Neighbourhood & $\begin{array}{l}\text { Proximity to airport } \\
\text { Distance to crime area } \\
\text { Proximity to hospital }\end{array}$ & $\begin{array}{l}\text { Li \& Brown (1980) } \\
\text { Feitelson, Hurd, \& Mudge (1996) } \\
\text { Huh \& Kwak (1997) } \\
\text { Tomkins, Topham, Twomey, \& Ward (1998) } \\
\text { Espey \& Lopez (2000) }\end{array}$ \\
\hline \multicolumn{2}{|l|}{$\begin{array}{l}\text { Environment } \\
\text { Quality of air } \\
\text { Quality of water } \\
\text { Frequency of flooding }\end{array}$} & $\begin{array}{l}\text { Lamond \& Proverbs (2006) } \\
\text { Ismail, Karim, \& Hasan-Basri (2014) } \\
\text { Ismail, Karim, \& Hasan-Basri (2016) }\end{array}$ \\
\hline
\end{tabular}

a differentiated good will maximise his utility when his indifference curve is tangent to the hedonic price function. Using the first order conditions from a consumer optimisation problem, Rosen showed that the marginal rate of substitution between a characteristic of the differentiated good and the numeraire good is equal to the gradient of the hedonic price function, evaluated at the optimal levels of product characteristics. Therefore, the gradient of the hedonic price function helps to identify the marginal willingness to pay for product characteristics from the tangencies.

Blow, Browning and Crawford (2008) estimated consumers' willingness to pay by embedding a characteristic model of utility in a revealed preference method. In the hedonic literature, studies done by Bajari and Benkard (2005), Benkard and Bajari (2005), Erickson and Pakes (2011) and Pakes (2003) focussed on willingness to pay on discrete choices in imperfectly competitive markets. Besides that, Triplett (2004) also presented a comprehensive discussion of the use of hedonic methods in constructing price indexes and willingness to pay. Since the hedonic price function is determined by the interaction of demand, cost and competitive conditions (Hausman, 2003), studies done by Kanemoto (1988), Pakes (2003), Pollak (1989) and Scotchmer (1985) showed that hedonic prices can be used to bound willingness to pay. In addition, there are several other studies that apply willingness to pay using the hedonic method such as Goodman (1983), who analysed willingness to pay for year 1975 car models efficiency; Moaz (2005), who assessed the willingness to pay for air quality in Metropolitan Damascus; and Othman, Othman and Mohd Noor (2006), who estimated households' willingness to pay for average air quality in Malaysia. 
Apart from that, a previous study done by Breffle, Morey and Lodder (1998) also suggests that a consumer's willingness to pay for improved environmental amenities is a function of household characteristics. A number of household characteristics including income, gender, education and knowledge about an environment issue have been found to be statistically significant in explaining the willingness to pay for environmental goods and services (Bowker, Newman, Warren, \& Henderson, 2003; Choe, Whittington, \& Lauria, 1996). Therefore, willingness to pay for a reduction in environmental risk such as floods may depend on factors such as risk perception, resource limitations, personality, current risk level and acceptability of risks. According to Garrod and Willis (1992), whether an individual is willing to pay or not depends on whether his utility reaches a maximum, which is strictly confined to the addressed factors.

\section{Methodology}

This study builds on existing literature that deals with flood attributes by including a flood variable into the hedonic model. Many researchers have successfully implemented HPM to study the effect of flooding on the changes in house prices. HPM enables the researcher to determine the possible effect of each attribute on the price of the property being analysed. As listed in Table 1, the attributes that affect the prices of residential properties are flood (as a component of environment), location, structure and neighbourhood. The functional form of the model explaining property price using HPM is shown in Equation (1):

$$
P=f(F L O O D, L O C, S T R, N G H)
$$

where FLOOD represents the flood attribute. Meanwhile, LOC, STR, NGH represent the attributes of location, structure and neighbourhood, respectively of the residential property.

Basu and Thibodeau (1998) proposed the semi-log functional form because it can be used to correct the heteroscedasticity problem between house price and the residuals. Hence, the final log-linear equation in this study is defined in Equation (2):

$$
\begin{aligned}
& \ln P_{i}=\beta_{0}+\beta_{1} F R E_{i}+\beta_{2} B U S_{i}+\beta_{3} B U S_{i}^{2}+\beta_{4} C I T Y_{i}+\beta_{5} C I T Y_{i}^{2}+\beta_{6} L O T_{i}+ \\
& \beta_{7} A G E_{i}+\beta_{8} B E D_{i}+\beta_{9} B A T H_{i}+\beta_{10} D_{\text {AIRPORT }, i}+\beta_{11} D_{\text {SCHOOL }, i}+\mu_{i}
\end{aligned}
$$

where:

$\begin{array}{ll}P & =\text { residential property price } \\ \beta_{0}, \ldots, \beta_{11} & =\text { parameters to be estimated } \\ \mu & =\text { random error term } \\ F R E & =\text { flood frequency } \\ B U S & =\text { distance to the nearest bus station } \\ C I T Y & =\text { distance to the nearest city centre } \\ L O T & =\text { size of lot } \\ A G E & =\text { house age } \\ B E D & =\text { number of bedrooms } \\ B A T H & =\text { number of bathrooms }\end{array}$




$$
\begin{array}{ll}
D_{\text {AIRPORT }} & =\text { proximity to airport } \\
D_{\text {SCHOOL }} & =\text { proximity to school }
\end{array}
$$

In log-transformed explanatory variables, the estimated coefficients measure the price elasticities with respect to a given variable. We select the elements to be factored in each variable (i.e., location, structure and neighbourhood) based on previous studies. It is important to determine the appropriateness of the elements to be applied and tested in Malaysia. Based on the above discussion, the suggested hypotheses and expected signs of flood frequency, location, structure and neighbourhood variables are shown in Table 2.

Meanwhile, the second stage of HPM is based on Rosen's (1974) two stage procedure. Ekeland, Heckman and Nesheim (2004) applied the second stage approach which uses insights from the first stage to develop a set of exclusion restrictions to be used in identifying the marginal willingness to pay. Following the studies of Bin and Landry (2013), Garrod and Willis (1992), and Thompson and Stoevener (1983), the next step in the second stage is to estimate the implicit price of flood risk reduction for each observation, which is the responsiveness of the house price function with respect to the flood attributes.

According to Garrod and Willis (1992), this step is carried out where the implicit price obtained from Equation (2) is regressed against the flood attributes (e.g., flood damage and flood risk) and socio-economic variables. According to Devkota, Maraseni and Cockfield (2014) and Maraseni, Maroulis and Cockfield (2008), the socio-economic characteristics of the respondents such as income, age, gender and educational background also affect their willingness to pay. Therefore, the socio-economic variables

\begin{tabular}{|c|c|c|c|c|}
\hline Variables & Factor elements & Definition & Measurement (unit) & Expected sign \\
\hline RPV & - & $\begin{array}{l}\text { Current price of } \\
\text { residential property }\end{array}$ & Malaysian Ringgit (RM) & - \\
\hline FLOOD & FRE & Frequency of flood & Number of times & Negative \\
\hline \multirow[t]{2}{*}{ LOCATION } & BUS & $\begin{array}{l}\text { Distance to nearest } \\
\text { bus station }\end{array}$ & Kilometres (km) & Negative \\
\hline & CITY & $\begin{array}{l}\text { Distance to nearest } \\
\text { city centre }\end{array}$ & Kilometres (km) & Negative \\
\hline \multirow[t]{4}{*}{ STRUCTURE } & LOT & Lot size of house & Square foot (sq. ft.) & Positive \\
\hline & AGE & Age of house & Number of years & Positive \\
\hline & BATH & Number of bathroom & Unit of room & Positive \\
\hline & BED & Number of bedroom & Unit of room & Positive \\
\hline \multirow[t]{2}{*}{$\begin{array}{l}\text { NEIGHBOUR- } \\
\text { HOOD }\end{array}$} & $\mathrm{D}_{\text {AIRPORT }}$ & $\begin{array}{l}\text { Dummy proximity to } \\
\text { airport }\end{array}$ & $\begin{array}{l}\text { 1: distance within } 10 \mathrm{~km} \\
0: \text { distance above } 10 \mathrm{~km}\end{array}$ & Negative \\
\hline & $\mathrm{D}_{\mathrm{SCHOOL}}$ & $\begin{array}{l}\text { Dummy proximity to } \\
\text { school }\end{array}$ & $\begin{array}{l}\text { 1: distance within } 2 \mathrm{~km} \\
0: \text { distance above } 2 \mathrm{~km}\end{array}$ & Positive \\
\hline
\end{tabular}

Table 2. Expected signs of the coefficients of variables 
used in this study are the respondents' income, age and level of education. Then, the estimated implicit price is regressed againsts the flood attributes and socio-economic variables. The functional form of the implicit inverse demand function is specified in Equation (3):

$$
\begin{aligned}
\operatorname{In} I M P_{i}= & \beta_{0}+\beta_{1} D A M A G E_{i t}+\beta_{2} D_{\text {MOVE }, i t}+\beta_{3} D_{\text {INCOME }, \text { it }}+\beta_{4} D_{\text {EDUCATION }, i t}+ \\
& \beta_{5} A G E_{i t}+\beta_{6} D_{\text {FINCON }, i t}+\mu_{i}
\end{aligned}
$$

where IMP is the implicit price. DAMAGE, $D_{\text {MOVE }}, D_{\text {INCOME }}$ AGE and $D_{\text {EDUCATION }}$ are matrices of respondent's total house damages due to flood, dummy flood risk averse, dummy respondent's income, age and dummy level of education, respectively. The variable $D_{\text {FINCON }}$ is an interaction term between $D_{\text {INCOME }}$ and $D_{\text {MOVE }}$.

Based on the above discussion, the suggested hypotheses and expected signs of flood and socio-economic variables are shown in Table 3.

\begin{tabular}{|c|c|c|c|c|}
\hline Variables & Factor elements & Definition & Measurement (unit) & Expected sign \\
\hline IMP & - & Implicit price & Malaysian Ringgit (RM) & - \\
\hline \multirow[t]{2}{*}{ FLOOD } & DAMAGE & $\begin{array}{l}\text { Cost of structural } \\
\text { damage to the house } \\
\text { due to flood event }\end{array}$ & Malaysian Ringgit (RM) & Positive \\
\hline & $D_{\text {MOVE }}$ & $\begin{array}{l}\text { Dummy intention to } \\
\text { move or not to move } \\
\text { to the flood free } \\
\text { location }\end{array}$ & $\begin{array}{l}\text { 1: planning to move to } \\
\text { the flood free location } \\
0: \text { not planning to move } \\
\text { to the flood free location }\end{array}$ & Positive \\
\hline \multirow[t]{4}{*}{$\begin{array}{l}\text { SOCIO- } \\
\text { ECONOMIC }\end{array}$} & $D_{\text {INCOME }}$ & $\begin{array}{l}\text { Dummy respondent's } \\
\text { income/salary }\end{array}$ & $\begin{array}{l}\text { 1: income above } \mathrm{RM} 3,051 \\
0 \text { : income below } \mathrm{RM} 3,050\end{array}$ & Positive \\
\hline & $D_{\text {EDUCATION }}$ & $\begin{array}{l}\text { Dummy respondent's } \\
\text { level of education }\end{array}$ & $\begin{array}{l}\text { 1: university level of } \\
\text { education } \\
0: \text { otherwise }\end{array}$ & Positive \\
\hline & AGE & Respondent's age & Years & Positive \\
\hline & $D_{\text {FINCON }}$ & $\begin{array}{l}\text { Dummy of financial } \\
\text { constraint }\end{array}$ & $\begin{array}{l}\text { Interaction term between } \\
D_{\text {INCOME }} \text { and } D_{\text {MOVE }}\end{array}$ & Positive \\
\hline
\end{tabular}

Table 3. Expected signs of the coefficients of variables

\subsection{Data and Sources}

The target population in this study is comprised of households in Malaysia that have been affected by flooding from 2008 to 2013. We used stratified sampling method to highlight a specific subgroup in the population; the entire target population was divided into different subpopulations. In order to obtain a stratified sample of flood victims, we first organised the population by states and by districts. For each state, we choose two districts to be selected in our study. Since our study area covers the whole of Peninsular Malaysia, we narrow down the scope to those districts that had been flooded in the past. The sampling frame used in this study are two districts per state that had been previously flooded. 
The two districts (one rural and one urban) selected for each state must have experienced either major or minor flooding. Thus, in each state, the sample will have one district with major and one with minor floods (except in the state where there are only urban districts like Penang). This is to ensure that the study is able to capture the effects of both major and minor flood events that occur in urban and rural residential land areas in Malaysia. If there are more than two districts in a state that fulfils the selection criteria, we randomly select two districts as a sample of study.

In the context of flood severity, the Department of Drainage and Irrigation Malaysia (DID) has categorised level of flooding into major and minor floods. A major flood is a situation where the areas affected suffer extensive damage, massive loss and the number of people who have to be housed at evacuation centres exceeds 1,000.

The classification of urban and rural areas based on strata according to Department of Statistic Malaysia (DOSM) (2000) is divided into four major strata. ${ }^{1}$ The DOSM

Table 4. List of states, districts and parameters

\begin{tabular}{|c|c|c|}
\hline State & City/District & Description \\
\hline Perlis & $\begin{array}{l}\text { Padang Besar } \\
\text { Arau }\end{array}$ & $\begin{array}{l}\text { Minor flooding occurred in urban area } \\
\text { Major flooding occurred in rural area }\end{array}$ \\
\hline Kedah & $\begin{array}{l}\text { Kota Setar } \\
\text { Kuala Muda }\end{array}$ & $\begin{array}{l}\text { Major flooding occurred in urban area } \\
\text { Minor flooding occurred in rural area }\end{array}$ \\
\hline Pulau Pinang & S.P. Utara & Minor flooding occurred in urban area \\
\hline Perak & $\begin{array}{l}\text { Manjung } \\
\text { Kerian, Larut Matang and Selama }\end{array}$ & $\begin{array}{l}\text { Minor flooding occurred in urban area } \\
\text { Major flooding occurred in rural area }\end{array}$ \\
\hline Selangor & $\begin{array}{l}\text { Sepang } \\
\text { Kuala Selangor }\end{array}$ & $\begin{array}{l}\text { Major flooding occurred in urban area } \\
\text { Minor flooding occurred in rural area }\end{array}$ \\
\hline Negeri Sembilan & Jelebu & Minor flooding occurred in rural area \\
\hline Melaka & $\begin{array}{l}\text { Alor Gajah } \\
\text { Melaka Tengah }\end{array}$ & $\begin{array}{l}\text { Major flooding occurred in urban area } \\
\text { Minor flooding occurred in rural area }\end{array}$ \\
\hline Johor & $\begin{array}{l}\text { Johor Bahru } \\
\text { Segamat }\end{array}$ & $\begin{array}{l}\text { Minor flooding occurred in urban area } \\
\text { Major flooding occurred in rural area }\end{array}$ \\
\hline Pahang & $\begin{array}{l}\text { Kuantan } \\
\text { Rompin }\end{array}$ & $\begin{array}{l}\text { Major flooding occurred in urban area } \\
\text { Minor flooding occurred in rural area }\end{array}$ \\
\hline Kelantan & $\begin{array}{l}\text { Pasir Mas } \\
\text { Tumpat }\end{array}$ & $\begin{array}{l}\text { Minor flooding occurred in urban area } \\
\text { Major flooding occurred in rural area }\end{array}$ \\
\hline Terengganu & $\begin{array}{l}\text { Dungun } \\
\text { Besut }\end{array}$ & $\begin{array}{l}\text { Major flooding occurred in urban area } \\
\text { Minor flooding occurred in rural area }\end{array}$ \\
\hline
\end{tabular}

Source: Department of Drainage and Irrigation Malaysia and Department of Statistics Malaysia.

1 The classification of area according to the four major strata are as follows: metropolitan is an area where the population exceeds 75,000 , big or large city/town is an area with a population between 10,000 and 74,999 , small city/town is an area with a population between 1,000 and 74,999 , and rural is an area with a population below 1,000 . 
Table 5. Statistics of flood frequency distribution by state, district and year of occurrence in Peninsular Malaysia

\begin{tabular}{|c|c|c|c|c|c|c|c|}
\hline State & District & 2008 & 2009 & 2010 & 2011 & 2012 & 2013 \\
\hline \multirow[t]{2}{*}{ Perlis } & Padang Besar & 1 & 1 & 1 & 2 & 2 & 1 \\
\hline & Arau & 1 & 1 & 1 & 2 & 2 & 2 \\
\hline \multirow[t]{2}{*}{ Kedah } & Kota Setar & 1 & 3 & 1 & 2 & 2 & 3 \\
\hline & Kuala Muda & 3 & 2 & 1 & 4 & 3 & 2 \\
\hline Pulau Pinang & S.P. Utara & 2 & 5 & 3 & 5 & 3 & 3 \\
\hline \multirow[t]{2}{*}{ Perak } & $\begin{array}{l}\text { Kerian, Larut Matang } \\
\text { and Selama }\end{array}$ & 2 & 5 & 5 & 3 & 3 & 3 \\
\hline & Manjung & 5 & 3 & 2 & 3 & 3 & 2 \\
\hline \multirow[t]{2}{*}{ Selangor } & Kuala Selangor & 8 & 2 & 3 & 7 & 4 & 4 \\
\hline & Sepang & 2 & 6 & 10 & 8 & 6 & 6 \\
\hline Negeri Sembilan & Jelebu & 3 & 1 & 4 & 4 & 3 & 3 \\
\hline \multirow[t]{2}{*}{ Melaka } & Alor Gajah & 4 & 1 & 1 & 2 & 3 & 2 \\
\hline & Melaka Tengah & 3 & 3 & 1 & 1 & 2 & 1 \\
\hline \multirow[t]{2}{*}{ Johor } & Segamat & 2 & 1 & 2 & 2 & 1 & 2 \\
\hline & Johor Bahru & 5 & 5 & 4 & 3 & 3 & 3 \\
\hline \multirow[t]{2}{*}{ Pahang } & Rompin & 2 & 1 & 1 & 3 & 3 & 3 \\
\hline & Kuantan & 3 & 1 & 2 & 2 & 2 & 2 \\
\hline \multirow[t]{2}{*}{ Kelantan } & Tumpat & 2 & 3 & 3 & 2 & 3 & 2 \\
\hline & Pasir Mas & 2 & 3 & 3 & 3 & 3 & 3 \\
\hline \multirow[t]{2}{*}{ Terengganu } & Dungun & 1 & 3 & 2 & 2 & 3 & 3 \\
\hline & Besut & 2 & 3 & 3 & 3 & 2 & 3 \\
\hline
\end{tabular}

Source: Department of Drainage and Irrigation (DID) Malaysia.

categorises the strata as urban area if it is metropolitan, large or big cities/towns and rural area if it is either small cities/towns or rural. In total, twenty districts are selected for this study. The list of states, districts and parameters that are used are presented in Table 4.

Then, we conduct a random sampling of homeowners from the rural and urban areas, and ensure that a sufficient number of respondents have been selected for each group in the final sample. Information on flood frequency distributions and the year of occurrence in the selected sample areas are presented in Table 5. This information is obtained from the Department of Irrigation and Drainage (DID), Department of Statistics Malaysia (DOSM), the local council, and the Malaysian Department of Social Welfare.

Information on current house price is obtained from the Malaysian Property Market Report and National Property Information Centre (NAPIC) ${ }^{2}$. Only full brick

2 Certain data on house price is requested directly from NAPIC based on the respondent's specific residential property address. The house price is calculated based on the average house price in a particular street or house area. 
houses are selected for this study. Meanwhile, distance variables such as distance to nearest bus stop, distance to nearest city centre, proximity to airport and proximity to school are obtained from Google Maps (Google, n.d.).

\subsection{Results and Discussions}

A total of 1,486 respondents were interviewed in this study. However, only about 91.52 per cent or 1,360 respondents responded to the interview; the remaining 8.48 percent or 126 respondents declined to be interviewed due to time constraints. A majority of the respondents have busy work schedules and irregular working hours, which makes it difficult for them to accommodate our interview session.

In particular, 700 respondents were property owners who had experienced flooding. The list of flood victims who still resides in the same areas that had been flooded was acquired from the Department of Social Welfare and from the local councils. The remaining 660 respondents who were not affected by flood in the area were also included in this study to avoid sample selection bias problem.

Table 6 presents the descriptive statistics of the variables. It shows that at most, the study areas have been flooded three times within a five-year period (2008-2013). According to the Department of Irrigation and Drainage, most of the flood prone areas covered in this study experienced three flood events a year. For example, Larut Matang and Selama (one of our sample districts) were flooded five times in 2010; once in August 2010, three in September 2010, and another one in November 2010. The average cost of structural damage to the respondent's house due to the flood event is RM966 including damage to the external and internal house structures. Based on the survey responses, the types of house structure damages recorded are paint cracks on

Table 6. Descriptive statistics of variables used in the first stage and second stage of residential property value model

\begin{tabular}{lrrr}
\hline Variable & Mean & Minimum & Maximum \\
\hline RPV (in RM per unit property) & $266,080.73$ & $69,600.00$ & $590,000.00$ \\
Flood: & & & \\
$\quad$ FREQUENCY (number of flood & 3.13 & 1.00 & 5.00 \\
$\quad$ occurrences in 5 years) & & & \\
$\quad$ DAMAGE (RM) & 966.00 & 200.00 & 8000.00 \\
Location: & & & \\
$\quad$ BUS (in kilometres) & 2.36 & 0.70 & 10.60 \\
CITY (in kilometres) & 3.78 & 0.80 & 11.00 \\
Structural: & $1,516.73$ & $1,200.00$ & $1,600.00$ \\
$\quad$ LOT (per square foot) & 15.00 & 8.00 & 20.00 \\
$\quad$ AGE (number of years) & 3.13 & 1.00 & 7.00 \\
BED (number of rooms) & 2.04 & 1.00 & 4.00 \\
$\quad$ BATH (number of rooms) & & & \\
\hline
\end{tabular}

Source: Authors' survey. 
the wall, spoiled flooring, jammed or broken windows and doors, and some wreckage of the electrical system including switches and wiring.

This study covers both low cost and high cost properties where the sale prices or residential property values (RPV) are between RM69,600 to RM590,000. The significant variations between the low cost and high cost property prices are due to the differences in the study areas which cover the urban and rural areas. The residential properties included in this study are located about $0.7 \mathrm{~km}$ and $0.8 \mathrm{~km}$ from the nearest bus station and city centre, respectively. Lot sizes of the sample residential properties can be considered moderate to large, with lot size averaging 1,516 sq. $\mathrm{ft}$. The age of the properties surveyed range from 8-20 years. At most, the properties have seven bedrooms and six bathrooms.

\subsection{First-stage Hedonic Regression}

The first objective of this study is to investigate the effect of flood frequency on RPV in urban and rural areas in Malaysia. For this purpose, we use the semi-log functional form (dependent), which can correct heteroscedasticity and multicollinearity problems (Basu and Thibodeau, 1998). Table 7 presents the result of the first-stage hedonic regression.

Based on the results in Table 7, flood frequency in both urban and rural areas are negatively and statistically significant. The results explain that if flood frequency increases by one flood event per year, the residential property value significantly decreases by 18.5 percent and 13.6 percent in the urban and rural areas, respectively. The value of flood coefficient in the urban area is higher compared to the estimate in the rural area. This indicates that flood frequency causes the residential property value in the urban area to decline more than the property value in the rural area. Most of the urban residents are wealthier than the rural residents where the average income of urban residents is $\mathrm{RM} 2,000$ more than the average income of rural residents (DOSM, 2013). Therefore, urban residents can afford to pay a higher price for residential property in the urban area whereby most of the property has more valuable extras (NAPIC, 2014). Thus, floods that hit the urban area will have a greater effect on the urban property value compared to the rural area.

Location is another important attribute that affects potential buyers' housing choices. The urban-area CITY coefficient is positive and statistically significant but the coefficient of $C I T Y^{2}$ is negatively significant implying that residential properties located near the city centre of urban areas have lower market values than those that are farther from the city centre. However, up to a certain distance, the farther the distance from the city centre, the lower the value of the residential properties. Buyers prefer to acquire residential properties farther away from the city but to a certain extent especially away from industrial zones - because such city and industrial areas are more exposed to air pollution, which is hazardous to health (Schwarz \& Marcus, 1990). Thus, this causes low demand for residential properties located in the city and its surrounding areas, thereby affecting their property market value.

The structure of a house can be analysed in terms of lot size, house age and number of bathrooms and bedrooms. Coefficients for the lot size (LOT), number of bedroom $(B E D)$ and number of bathroom $(B A T H)$ for both urban and rural areas are 
Table 7. Estimation results of the first-stage hedonic regression

\begin{tabular}{|c|c|c|c|c|}
\hline \multirow{3}{*}{ Variable } & \multicolumn{4}{|c|}{ Coefficient } \\
\hline & \multicolumn{2}{|c|}{ Urban area } & \multicolumn{2}{|c|}{ Rural area } \\
\hline & Coefficient & Standard error & Coefficient & Standard error \\
\hline Constant & $11.553^{* * *}$ & $(0.173)$ & $11.336^{* * *}$ & $(0.216)$ \\
\hline \multicolumn{5}{|l|}{ Flood: } \\
\hline FRE & $-0.185^{* * *}$ & $(0.070)$ & $-0.136^{*}$ & $(0.081)$ \\
\hline \multicolumn{5}{|l|}{ Location: } \\
\hline BUS & -0.016 & $(0.011)$ & 0.003 & $(0.006)$ \\
\hline BUS $^{2}$ & 0.0001 & $(0.0001)$ & -0.0001 & $(0.0003)$ \\
\hline CITY & $0.041 * * *$ & $(0.012)$ & -0.010 & $(0.008)$ \\
\hline $\mathrm{CITY}^{2}$ & $-0.001 * * *$ & $(0.0003)$ & 0.0003 & $(0.0003)$ \\
\hline \multicolumn{5}{|l|}{ Structure: } \\
\hline LOT & $0.0001 * * *$ & (0.00005) & $0.0001 * * *$ & (0.00004) \\
\hline AGE & $-0.012 * * *$ & $(0.003)$ & $-0.010 * * *$ & $(0.002)$ \\
\hline BED & $0.077 * * *$ & $(0.034)$ & $0.059 * *$ & $(0.045)$ \\
\hline BATH & $0.233^{* * *}$ & $(0.035)$ & $0.180 * * *$ & $(0.042)$ \\
\hline \multicolumn{5}{|l|}{ Neighbourhood: } \\
\hline $\mathrm{D}_{\text {AIRPORT }}$ & 0.059 & $(0.074)$ & -0.112 & $(0.090)$ \\
\hline $\mathrm{D}_{\text {SCHOOL }}$ & -0.139 & $(0.094)$ & $0.256^{*}$ & $(0.137)$ \\
\hline No. of observations & \multicolumn{2}{|c|}{680} & \multicolumn{2}{|c|}{680} \\
\hline $\mathrm{R}^{2}$ & \multicolumn{2}{|c|}{53.90} & \multicolumn{2}{|c|}{47.00} \\
\hline Adjusted $\mathrm{R}^{2}$ & \multicolumn{2}{|c|}{52.40} & \multicolumn{2}{|c|}{45.30} \\
\hline F-Statistic & \multicolumn{2}{|c|}{$\begin{array}{c}36.57 \\
(0.000)\end{array}$} & \multicolumn{2}{|c|}{$\begin{array}{l}27.811 \\
(0.000)\end{array}$} \\
\hline
\end{tabular}

Note: $* * *$, and $* * *$ refer to figures that are significant at $10 \%, 5 \%$, and $1 \%$ levels of significance, respectively.

positive and significant. An increase in the lot size usually adds to the value, because it gives the property owners room to expand such as adding more bedrooms and bathrooms. In fact, building additional rooms (bathroom or bedroom) will increase construction costs, which will consequently increase the value of a residential property.

The coefficients of house age $(A G E)$ for both urban and rural areas are negative and statistically significant. Generally, as a property gets older, it becomes less valuable because a lot of work will be needed for repairs and upgrading the condition as well as to maintain it. In fact, based on the assumption that older homes may have outdated technology as well as lacking a number of features available in newer homes, this would decrease the benefits provided by the property. Therefore, this will lower the value of the property.

In the neighbourhood characteristics, all of the urban and rural areas $D_{\text {AIRPORT }}$ coefficients show insignificant results. Conversely, coefficient of proximity to school $\left(D_{\text {SснооL }}\right)$ shows a positive and significant result only in the rural area. This probable 
reason may be due to the limited number of schools in the rural area while a number of them are located far from certain residential areas. For example, in Selangor, a rural area such as Kapar only has ten primary schools and two secondary schools, compared to the number of schools in urban areas, such as the city of Klang, which has a total of 75 primary schools and 36 secondary schools (Ministry of Education Malaysia, 2014a; 2014b). For these reasons, buyers in the rural area prefer to choose a residential property located near to a school.

\subsection{Results of the Second-stage Regression}

The second objective of this paper is to determine the consumer's willingness to pay for flood control measures to reduce the impact of flood risk. Implicit price measures the amount of money that individuals are willing to pay to keep their utility at original levels. The economic welfare that we used in this study involves a household's comfort and satisfaction of their current living standards of being able to avoid the damages and inconveniences brought by flooding. Thus, in our study, implicit price refers to the estimates of economic welfare of households, as measured by their willingness to pay for flood mitigation measures to reduce the flood risk.

The calculation of implicit price represents an empirically implementable measure of consumer's willingness to pay for flood mitigation project to reduce the impact of flood risk. The implicit price can be calculated by using the formula as in Equation (4)

$$
\text { Implicit Price }=\frac{\partial R P V}{\partial F R E Q U E N C Y}=\frac{\text { coefficient of FREQUENCY }}{\text { FREQUENCY }} \times R P V
$$

The total implicit price provided by respondents is calculated as RM4,461,878 for approaches to avoid losses in residential property value due to flood risk problems. The estimation of the individual amount can be calculated by dividing the total implicit price with the number of respondents. On average, the individual respondent's implicit price for a flood management programme to reduce the flood risk problems in their residential area is about $\mathrm{RM} 2,280$. The total value of implicit price of $\mathrm{RM} 4,461,878$ or RM4.4 million calculated corresponds with the cost incurred by the government in the implementation of several flood mitigation projects such as river widening and deepening work, upgrading and modifying infrastructure and irrigation system and river maintenance work. For example, based on the report from the Perak Department of Drainage and Irrigation 2015/2016, the total cost of the flood mitigation project and the maintenance of several rivers in Perak such as Sungai Bidor and Sungai Lamin is about RM4.1 million.

The close value between the flood control project's actual cost and the estimated amount of households' implicit price shows that this study can provide a good estimate

For example, for observation 1 (or sample 1), suppose the residential property value (RPV) is RM100,000, coefficient of flood frequency (FRE) is 0.185 and variable flood frequency (FRE) is 3 times. The implicit price using the formula would be $(0.185 / 3) \times 100000=6166.67$. Therefore, the implicit price is RM6,166.67. To compute the total implicit price, we need to add all the implicit prices for each observation. 
for flood management policy implementation, where the government can collect money from households for flood mitigation purposes rather than fully financing the flood project, since the respondents are willing to spend more money on flood mitigation projects in order to reduce the flood risk problems.

The purpose of estimating the second stage hedonic regression model where the measure of willingness to pay is included as an dependent variable is to see the effect of socio-economic factors and risk on the willingness to pay to reduce flood risk. Table 8 presents the results of the second-stage hedonic regression.

The positive and statistically significant coefficient of risk taking $\left(D_{\text {MOVE }}\right)$ shows that respondents who are risk averse, indicated by those who are planning to move to other flood free location, are willing to pay more money compared to those who are risk takers. A study done by Cameron and Shah (2015) found that natural disasters can impact real life behaviour through decreased risk taking behaviour. Commonly, after the post flood events, developers usually do not take on the full risk of responsibilities of the property in areas that are prone to flooding. Therefore, for the flood risk adverse group, they are willing to pay higher for flood control measures to reduce the impact of flood risk, so as not having to move from the area.

Table 8. Estimates of the second-stage hedonic regression

\begin{tabular}{|c|c|c|}
\hline Variable & Coefficient & Std. deviation \\
\hline Constant & $8.414 * * *$ & 0.229 \\
\hline \multicolumn{3}{|l|}{ Flood } \\
\hline DAMAGE & 0.00046 & 0.0039 \\
\hline $\begin{array}{l}\mathrm{D}_{\text {MOVE }} \\
\text { (1= planning to move; } \\
0=\text { not moving) }\end{array}$ & $0.357 * * *$ & 0.115 \\
\hline \multicolumn{3}{|l|}{ Socio-economic profile } \\
\hline $\begin{array}{l}D_{\text {INCOME }} \\
(1=\text { above } R M 3,050 ; \\
0 \text { = below RM3,051) }\end{array}$ & $0.132 *$ & 0.096 \\
\hline $\begin{array}{l}D_{\text {EDUCATION }} \\
\text { (1= university; } \\
0=\text { otherwise) }\end{array}$ & $0.347^{* *}$ & 0.137 \\
\hline AGE & $-0.010 * *$ & 0.004 \\
\hline$D_{\text {FINCON }}$ & -0.065 & 0.043 \\
\hline No. of observations & & \\
\hline $\mathrm{R}^{2}$ & & \\
\hline Adjusted $\mathrm{R}^{2}$ & & \\
\hline F-Statistic & & \\
\hline
\end{tabular}


However, the value for the coefficient of DAMAGE is statistically insignificant. This shows that the cost of structural damage to the house due to a flood event does not affect the respondent's willingness to pay for flood control measures. This may be due to the fact that most of the respondents in this study had experienced flooding more than once. As such, they have made preparations such as installing temporary barriers and upgrading permanent defences and resilient equipment on the house structure to reduce damage and loss from floods. In fact, based on the survey (as presented in the descriptive statistics), the average house structural damage cost incurred by the 631 respondents who experienced flood events more than once is small (even under RM1000). Therefore, the cost of structural damage to the house due to a flood event does not significantly affect the decision of respondent's willingness to pay for flood control measures to reduce flood risk.

Other socio-economic factors such as income, age and education level have influenced the level of willingness to pay (Devkota et al., 2014; Maraseni et al., 2008). The coefficient of household income $\left(D_{\text {INCOME }}\right)$ is positive and statistically significant. Generally, when household income increases, households' spending ability will improve, thereby improving their economic welfare. This means that they would be willing to pay to maintain the same level of economic welfare. Based on the Malaysian Household Income and Basic Amenities Survey Spending Report 2013, there is an increase of 6.13 percent in household income over two years between 2012 and 2013. Therefore, with the increase in income and spending ability, residents willingness to pay for flood management programmes also increases.

A positive and statistically significant coefficient of education level ( $D_{\text {EDUCATION }}$ ) indicates that households that possess a university qualification tend to have a higher willingness to pay for flood reduction programmes compared to those households without a university education. This may be because university graduates are more exposed to environmental issues (i.e., flood disasters), which would make them more likely to be more concerned and knowledgeable about flood and its management programmes. Thus, they would be more capable of assessing flood risks and the potential damage to properties as compared to those with a lower educational attainment. This is also consistent with the findings of an income report where according to the Public Services Commission of Malaysia, the starting salary of a university graduate is on average $\mathrm{RM} 2,500$ higher than those with a lower educational attainment. Therefore, this would make the university graduate respondents willing to spend more money for flood control measures due to their higher financial capacity.

Based on the result, the coefficient of age $(A G E)$ is negative and statistically significant. As age increases, some of the older households who are phasing into retirement may deal with lower pay and also some are likely to retire early due to poor health. As a result of the uncertainty and lower income received by the older household, this may affect their willingness to spend for flood control measures to reduce flood risk. Hence, increase in age will reduce the household willingness to pay for flood management programmes. On the other hand, the coefficient of financial constraint $\left(D_{\text {FINCON }}\right)$ is statistically insignificant. This shows that the effect of respondent's income on willingness to pay for flood control measures is not influenced by the respondent's decision to move or not from the flood prone area $\left(D_{\text {MOVE }}\right)$. 


\section{Conclusion and Policy Implication}

Our study confirms the results of earlier studies, which reported that repeated flooding of residential areas adversely affects the values of those properties located in the flood prone areas because these properties are at high risk of being seriously damaged due to flooding. Previous literature has demonstrated that the hedonic pricing model (HPM) is highly useful in analysing the relationship between property attributes and property prices. HPM tends to indicate that RPV are correlated to the location, structure, and neighbourhood attributes of the property. Our results show that most of the coefficients of location ( $L O C$ ), structure (STR), and neighbourhood (NGH) are statistically significant and have the expected signs. Therefore, these attributes can be priced in a similar way in Malaysia as with other countries. Further, HPM accurately portrays the attributes that property buyers prefer in a particular residential property. Such information can help developers to provide quality property to its clientele as they can better predict what the buyers want.

This study also calculated the implicit price of the respondents' willingness to pay for flood mitigation measures to reduce flood risk in their areas. Based on this study, the respondents are willing to pay about RM4.4 million for flood management and mitigation projects to minimise flood problems. In addition, on average, a respondent is willing to pay about RM2,280 for a flood management and mitigation project to reduce the flood risk in his area. Besides this, the study shows that respondents who are risk averse are willing to pay more money compared to those who are risk takers. Our results show that the socio-economic characteristics as measured by income, age, and educational level are highly significant in influencing their willingness to pay for flood mitigation projects to avoid damages and inconveniences caused by flooding.

As a solution, structural and nonstructural flood mitigation measures should be implemented which can provide an immediate solution to address such flooding problems in residential areas. The flood control projects (e.g., riverbank improvement, widening and deepening of river channels, and improving drainage and river bunds) can help in reducing repeated flooding and ensure that damages to and losses of properties due to floods are minimised.

In addition, the government should also introduce flood insurance schemes in the country since flooding is a major concern for real property owners. Currently, no flood insurance program exists in Malaysia; most of the standard insurance policies do not cover damages or losses due to "acts of God" such as flooding. At present, the Malaysian government provides ad-hoc flood relief aid to victims through monetary assistance amounting up to RM500 per affected household. However, its speed of disbursement is problematic, and the amount is not sufficient to finance the needed flood rehabilitation efforts. Therefore, a national insurance framework must be carefully designed and implemented to ensure that rehabilitation efforts will be properly funded, and that flood victims will be able to recover in due time.

\section{References}

Babcock, M., \& Mitchell, B. (1980). Impact of flood hazard on residential property prices in Galt (Cambridge), Ontario. Water Resources Bulletin, 16(3), 532-537. https://doi.org/10.1111/ j.1752-1688.1980.tb03908.x 
Bajari, P., \& Benkard, C.L. (2005). Demand estimation with heterogeneous consumers and unobserved product characteristics: A hedonic approach. Journal of Political Economy, 113(6), 1239-1276. https://doi.org/10.1086/498586

Basu, S., \& Thibodeau, T.G. (1998). Analysis of spatial autocorrelation in house prices. Journal of Real Estate Finance and Economics, 17(1), 61-85. https://doi.org/10.1023/A:1007703229507

Beksin, A.M. (2011). The effects of flooding on house prices: Two case studies in Malaysia (PhD thesis, Faculty of Built Environment, University of Malaya, Malaysia). Retrieved from http:// studentsrepo.um.edu.my

Benkard, C.L., \& Bajari, P. (2005). Hedonic price indexes with unobserved product characteristics and application to personal computers. Journal of Business \& Economic Statistics, 23(1), 6175. https://doi.org/10.1198/073500104000000262

Bin, O., \& Kruse, J.B. (2006). Real estate market response to coastal flood hazards. Natural Hazards Review, 7(4), 137-144. https://doi.org/10.1061/(ASCE)1527-6988(2006)7:4(137)

Bin, O., \& Landry, C.E. (2013). Changes in implicit flood risk premiums: Empirical evidence from the housing market. Journal of Environmental Economics and Management, 65(3), 361-376. https://doi.org/10.1016/j.jeem.2012.12.002

Bin, O., \& Polasky, S. (2004). Effects of flood hazards on property values: Evidence before and after Hurricane Floyd. Land Economics, 80(4), 490-500. https://doi.org/10.2307/3655805

Blow, L., Browning M., \& Crawford, I. (2008). Revealed preference analysis of characteristics models. Review of Economic Studies, 75(2), 371-389. https://doi.org/10.1111/j.1467-937X. 2008.00485.x

Bowker, J.M., Newman, D.H., Warren, R.J., \& Henderson, D.W. (2003). Estimating the economic value of lethal versus nonlethal deer control in suburban communities. Society and Natural Resources, 16(2), 143-158. https://doi.org/10.1080/08941920309197

Breffle, W.S., Morey, E.R., \& Lodder, T.S. (1998). Using contingent valuation to estimate a neighbourhood's willingness to pay to preserve undeveloped urban land. Urban Studies, 35(4), 715-727. https://doi.org/10.1080/0042098984718

Cameron, L., \& Shah, M. (2015). Risk-taking behavior in the wake of natural disasters. Journal of Human Resources, 50(2), 484-515. https://doi.org/10.3368/jhr.50.2.484

Carroll, T.M., Clauretie, T.M., \& Jensen, J. (1996). Living next to godliness: Residential property values and churches. Journal of Real Estate Finance and Economics, 12(3), 319-330. https:// doi.org/10.1007/BF00127540

Chan, N.W. (1996). Flood disaster management in Malaysia: An evaluation of the effectiveness of government resettlement schemes. Disaster Prevention and Management: An International Journal, 4(4), 22-29. https://doi.org/10.1108/09653569510093405

Chan, N.W. (1997). Increasing flood risk in Malaysia: Causes and solutions. Disaster Prevention and Management: An International Journal, 6(2), 72-86. https://doi.org/10.1108/096535697 10164035

Chau, K.W., Ma, V.S.M., \& Ho, D.C.W (2001). The pricing of 'luckiness' in the apartment market. Journal of Real Estate Literature, 9(1), 29-40.

Choe, K., Whittington, D., \& Lauria, D.T. (1996). The economic benefits of surface water quality improvements in developing countries: A case study of Davao, Philippines. Land Economics, 72(4), 519-537. https://doi.org/10.2307/3146913

Clapham, E., Englund, P., Quigley, J.M., \& Redfearn, C.L. (2004). Revisiting the past: Revision in repeat sales and hedonic indexes of house prices (Lusk Center for Real Estate Working Paper No. 2004/1011). Los Angeles, CA: USC Lusk Center for Real Estate.

Clark, D.E., \& Herrin, W.E. (2000). The impact of public school attributes on home sale price in California. Growth and Change, 31(3), 385-407. https://doi.org/10.1111/0017-4815.00134

DID (Department of Irrigation and Drainage Malaysia) (2008-2012). Flood Annual Report 20082012. Kuala Lumpur: Author. 
DID (Department of Irrigation and Drainage Perak). (2016). Annual Report 2015/2016. Retrieved from http://www.jpsperak.gov.my/userfiles/files/PDF/Publication/2017/LAPORAN\%20 TAHUNAN\%20JPS\%2020152016.pdf

DOSM (Department of Statistics Malaysia). (2000). Nota Keterangan: Definisi Luar Bandar. Retrieved from http://www.rurallink.gov.my/wp-content/uploads/2015/05/154.pdf

DOSM (Department of Statistics Malaysia). (2013). Report of Household Income and Basic Amenities Survey 2013. Putrajaya, Malaysia: Author.

Des Rosiers, F., Lagana, A., Thériault, M., \& Beaudoin, M. (1996). Shopping centres and house values: An empirical investigation. Journal of Property Valuation and Investment, 14(4), 4162. https://doi.org/10.1108/14635789610153461

Devkota, R.P., Maraseni, T.N., \& Cockfield, G. (2014). An assessment of willingness to pay to avoid climate change induce flood. Journal of Water and Climate Change, 5(4), 569-577. https:// doi.org/10.2166/wcc.2014.134

Ekeland, I., Heckman, J. J., \& Nesheim, L. (2004). Identification and estimation of hedonic models. Journal of Political Economy, 112(S1), S60-S109. https://doi.org/10.1086/379947

Erickson, T., \& Pakes, A. (2011). An experimental component index for the CPI: From annual computer data to monthly data on other goods. American Economic Review, 101(5), 17071738. https://doi.org/10.1257/aer.101.5.1707

Espey, M., \& Lopez, H. (2000). The impact of airport noise and proximity on residential property values. Growth and Change, 31(3), 408-419. https://doi.org/10.1111/0017-4815.00135

Eves, C. (2002). The long-term impact of flooding on residential property values. Property Management, 20(4), 214-227. https://doi.org/10.1108/02637470210444259

Eves, C. (2004). The impact of flooding on residential property buyer behaviour: An England and Australian comparison of flood affected property. Structural Survey, 22(2), 84-94. https://doi. org $/ 10.1108 / 02630800410538613$

Eves, C., Blake, A., \& Bryant, L. (2010). Assessing the impact of floods and flood legislation on residential property prices. Paper presented at the International Real Estate Research Symposium (IRES), 27-29 April 2010, Putra World Trade Centre, Kuala Lumpur. Retrieved from https://eprints.qut.edu.au/32599/1/c32599.pdf

Feitelson, E.I., Hurd, R.E., \& Mudge, R.R. (1996). The impact of airport noise on willingness to pay for residences. Transportation Research Part D: Transport and Environment, 1(1), 1-14. https://doi.org/10.1016/S1361-9209(96)00004-1

Fletcher, M., Gallimore, P., \& Mangan, J., (2000). Heteroskedasticity in hedonic house price models. Journal of Property Research, 17(2), 93-108. https://doi.org/10.1080/095999 100367930

Francke, M.K., Vos, G.A., \& Janssen, J.E. (2000). Standardised price indices for the regional housing market: A comparison between the fixed-sample index and the hedonic index. Paper presented at the 7th European Real Estate Society Conference, 14-16 June 2000, Bordeaux, France. Retrieved from https://www.academia.edu/19351376/STANDARDISED_PRICE_ INDICES_FOR_THE_REGIONAL_HOUSING_MARKET

Freeman, A.M. (1979). Hedonic prices, property values, and measuring environmental benefits: A survey of the issues. Scandinavian Journal of Economics, 81(2), 154-173. http://doi. org $/ 10.2307 / 3439957$

Fridgen, P.M., \& Shultz, S.D. (1999). The threat of flooding on housing values in Fargo, North Dakota and Moorhead, Minnesota. In E. Kendy (Ed.), Science into policy: Water in the public realm (pp. 77-82). Herndon, VA: American Water Resources Association.

Garrod, G.D., \& Willis, K.G. (1992). Valuing goods' characteristics: An application of the hedonic price method to environmental attributes. Journal of Environmental Management, 34(1), 5976. https://doi.org/10.1016/S0301-4797(05)80110-0 
Goodman, A.C. (1983). Willingness to pay for car efficiency: A hedonic price approach. Journal of Transport Economics and Policy, 17(3), 247-266.

Google. (n.d.). Malaysia. Retrieved from https://maps.google.com.my/

Handmer, J.W., \& Smith, D.I. (1990). Adjustment factors for flood damage curves. Journal of Water Resources Planning and Management, 116(6), 843-845.

Harrison, D.M., Smersh, G.T., \& Schwartz, A.L. (2001). Environmental determinants of housing prices: The impact of flood zone status. Journal of Real Estate Research, 21(1\&2), 1-20.

Hausman, J. (2003). Sources of bias and solutions to bias in the consumer price index. Journal of Economic Perspectives, 17(1), 23-44. https://doi.org/10.1257/089533003321164930

Hughes, J. (2000, November 11). Reduced: Riverside home with sandbags thrown in. The Times, London, UK, p. 12.

Huh, S., \& Kwak, S.-J. (1997). The choice of functional form and variables in the hedonic price model in Seoul. Urban Studies, 34(7), 989-998. https://doi.org/10.1080/0042098975691

IFRC (International Federation of Red Cross and Crescent Societies) (2009). World Disaster Report 2009: Focus on early warning, early action. Satigny/Vernier, Switzerland: ATAR Roto Presse.

Ismail, N.H., Karim, M.Z., \& Hasan-Basri, B. (2014). Does flood affect property values? A hedonic analysis of residential property values in peninsular Malaysia. Journal of Business Management and Accounting, 4(January), 1-14.

Ismail, N.H., Karim, M.Z. \& Hasan-Basri, B. (2016). Flood and land property values. Asian Social Science, 12(5), 84-93. https://doi.org/10.5539/ass.v12n5p84

Jha, A.K., Bloch, R., \& Lamond, J. (2012). Cities and flooding: A guide to integrated urban flood risk management for the 21st century. Washington, D.C., VA: World Bank Publications.

Kain, J.F., \& Quigley, J.M. (1970). Measuring the value of housing quality. Journal of the American Statistical Association, 65(330), 532-548. http://dx.doi.org/10.1080/01621459.1970.104811 02

Kanemoto, Y. (1988). Hedonic prices and the benefits of public projects. Econometrica, 56(4), 981989. https://doi.org/10.2307/1912708

Keng, T.Y. (2008). An hedonic model for house prices in Malaysia. Retrieved from www.prres.net/ papers/tan_an_hedonic_model_for_house_prices_in_malaysia.pdf

Khalid, M.S., \& Shafiai, S. (2015). Flood disaster management in Malaysia: An evaluation of the effectiveness flood delivery system. International Journal of Social Science and Humanity, 5(4), 398-402. http://doi.org/10.7763/IJSSH.2015.V5.488

Lambley, D.B., \& Cordery, I. (1991). Effects of floods on the housing market in Sydney. In International Hydrology and Water Resources Symposium (National Conference Publication 91/19) (pp. 863-866). Barton, Australia: The Institution of Engineers Australia.

Lamond, J., \& Proverbs, D. (2006). Does the price impact of flooding fade away? Structural Survey, 24(5), 363-377. https://doi.org/10.1108/02630800610711960

Li, M.M., \& Brown, H.J. (1980). Micro-neighbourhood externalities and hedonic housing prices. Land Economics, 56(2), 125-141. https://doi.org/10.2307/3145857

Ministry of Education Malaysia. (2014a). Bilangan Sekolah Rendah Mengikut Negeri. Retrieved from http://emisportal.moe.gov.my/

Ministry of Education Malaysia. (2014b). Bilangan Sekolah Menengah Mengikut Negeri. Retrieved from http://emisportal.moe.gov.my/

Maraseni, T.N., Maroulis, J., \& Cockfield, G. (2008). An estimation of willingness to pay for asparagus (Asparagus Racemosus Willd.) collector in Makawanpur District, Nepal. Journal of Forest Science, 54(3), 131-137. https://doi.org/10.17221/3099-JFS

Mar Iman, A.H., Hamidi, N., \& Liew, S. (2009). The effects of environmental disamenities on house prices. Malaysian Journal of Real Estate, 4(2), 32-44.

Meen, G. (2001). Modelling spatial housing markets: Theory, analysis, and policy. Norwell, MA: Kluwer Academic Publishers. 
Minnery, J.R., \& Smith, D.I. (1996). Climatic change, flooding and urban infrastructure. In W.J. Bosma, G.I. Pearman, \& M.R. Manning (Eds.), Greenhouse: Coping with climate change (pp. 235-247). Clayton, Australia: Commonwealth Scientific and Industrial Organization (CSIRO) Publishing..

Moaz, A.A. (2005). Hedonic valuation of marginal willingness to pay for air quality in metropolitan Damascus. Forum of International Development Studies, 30(September), 23-34.

Montz, B.E. (1992a). The effect of flooding on residential property values in three New Zealand communities. Disasters, 16(4), 283-298. https://doi.org/10.1111/j.1467-7717.1992.tb00411.x

Montz, B.E. (1992b). The impact of flood hazard area disclosure on property values in three New Zealand communities (Natural Hazard Research Working Paper No. 76). Boulder, CO: Natural Hazards Research and Applications Information Center, University of Colorado.

NAPIC (National Property Information Centre). (2014). Property Stock Report 2014. Putrajaya, Malaysia: Author.

Nicholas, J., Holt, G.D., \& Proverbs, D.G. (2001). Towards standardising the assessment of flood damaged properties in the UK. Structural Survey, 19(4), 163-172. https://doi.org/10.1108/ 02630800110406667

Othman, J., Othman, R., \& Mohd Noor, N. (2006). Welfare impacts of air quality changes in Malaysia: The hedonic pricing approach. Jurnal Ekonomi Malaysia, 40, 47-58.

Pakes, A. (2003). A reconsideration of hedonic price indexes with an application to PC's. The American Economic Review, 93(5), 1578-1596. https://doi.org/10.1257/00028280 3322655455

Pollak, R.A. (1989). The theory of the cost-of-living index. New York, NY: Oxford University Press.

Pope, J.C. (2008). Buyer information and the hedonic: The impact of a seller disclosure on the implicit price for airport noise. Journal of Urban Economics, 63(2), 498-516. https://doi. org/10.1016/j.jue.2007.03.003

PRC (Property Research Centre). (1992). Effect of flooding on residential property values (Final Report to the Upper Parramatta River Catchment Trust). Hawkesbury, Sydney: Faculty of Business and Land Economy, University of Western Sydney.

Queensland Flood Science, Engineering and Technology Panel (2012). Understanding the flood. Retrieved from http://www.chiefscientist.qld.gov.au/publications

Rahman, B.A. (2012). Issues of disaster management preparedness: A case study of directive 20 of National Security Council Malaysia. International Journal of Business and Social Science, 3(5), 85-92.

Ridker, R.G., \& Henning, J.A. (1967). The determinants of residential property values with special reference to air pollution. The Review of Economics and Statistics, 49(2), 246-257. https:// doi.org/10.2307/1928231

Rodriguez, M., \& Sirmans, C.F. (1994). Quantifying the value of a view in single-family housing markets. Appraisal Journal, 62(4), 600-603.

Rosen, S. (1974). Hedonic prices and implicit markets: Product differentiation in pure competition. Journal of Political Economy, 82(1), 34-55.

Samarasinghe, O., \& Sharp, B. (2010). Flood prone risk and amenity values: A spatial hedonic analysis. Australian Journal of Agricultural and Resource Economics, 54(4), 457-475. https:// doi.org/10.1111/j.1467-8489.2009.00483.x

Saptutyningsih, E., \& Suryanto, S. (2011). Hedonic price approach of flood effect on agricultural land. Economic Journal of Emerging Markets, 3(1), 87-96.

Schwarz, J., \& Marcus, A. (1990). Mortality and air pollution in London: A time series analysis. American Journal of Epidemiology, 131(1), 185-194. https://doi.org/10.1093/oxfordjournals. aje.a115473

Scotchmer, S. (1985). Hedonic prices and cost/benefit analysis. Journal of Economic Theory, 37(1), 55-75. https://doi.org/10.1016/0022-0531(85)90030-4 
Sheaffer, J.R., \& Greenberg, L.S. (1981). Evaluation of the economic, social, and environmental effects of floodplain regulations. Washington D.C., VA: US Department of Housing and Urban Development and the Federal Emergency Management Agency.

Shrubsole, D., \& Scherer, J. (1996). Floodplain regulation and the perceptions of the real state sector in Brantford and Cambridge, Ontario, Canada. Geoforum, 27(4), 509-525. https://doi. org/10.1016/S0016-7185(96)00024-3

Shultz, S.D., \& Fridgen, P.M. (2001). Floodplains and housing values: Implications for flood mitigation projects. Journal of the American Water Resources Association, 37(3), 595-603. https://doi.org/10.1111/j.1752-1688.2001.tb05496.x

Singh, H., \& Subramaniam, S. (2009). Health emergency and disaster preparedness in Malaysia. Southeast Asian Journal of Tropical Medicine Public Health, 40(1), 11-15.

Sirpal, R. (1994). Empirical modelling of the relative impacts of various sizes of shopping centres on the value of surrounding residential properties. Journal of Real Estate Research, 9(4), 487505.

Soentato, R., \& Proverbs, D.G. (2004). Impact of flood characteristics on damage caused to UK domestic properties: The perceptions of building surveyors. Structural Survey, 22(2), 95-104. https://doi.org/10.1108/02630800410538622

Speyrer, J.F., \& Ragas, W.R. (1991). Housing prices and flood risk: An examination using spline regression. Journal of Real Estate Finance and Economics, 4(4), 395-407.

Tang, F.T. (1975). Detection and estimation of transportation impact with models of urban residential property sales prices. Taipei, Taiwan: Institute of Economics, Academia Sinica.

Thompson, M.E., \& Stoevener, H.H. (1983). Estimating residential flood control benefits using implicit price equations. Journal of the American Water Resources Association, 19(6), 889896. https://doi.org/10.1111/j.1752-1688.1983.tb05937.x

Tobin, G.A., \& Montz, B.E. (1990). Response of the real estate market to frequent flooding: The case of Des Plaines, Illinois. Bulletin of the Illinois Geographical Society, 33(2), 11-21.

Tobin, G.A., \& Montz, B.E. (1994). The flood hazard and dynamics of the urban residential land market. Journal of the American Water Resources Association, 30(4), 673-685. https://doi. org/10.1111/j.1752-1688.1994.tb03322.x

Tomkins, J., Topham, N., Twomey, J., \& Ward, R. (1998). Noise versus access: The impact of an airport in an urban property market. Urban Studies, 35(2), 243-258. https://doi.org/10.1080/ 0042098984961

Triplett, J.E. (2004). Handbook on quality adjustment of price indexes for information and communication technology products (OECD Science, Technology and Industry Working Papers) Paris: OECD Directorate for Science, Technology and Industry. https://doi.org/ $10.1787 / 643587187107$

Troy, A., \& Romm, J. (2004). Assessing the price effects of flood hazard disclosure under the California natural hazards disclosure law (AB 1195). Journal of Environmental Planning and Management, 47(1), 137-62. https://doi.org/10.1080/0964056042000189844

Zhai, G., Fukuzono, T., \& Ikeda, S. (2003). Effect of flooding on megalopolitan land prices: A case study of the 2000 Tokai flood in Japan. Journal of Natural Disaster Science, 25(1), 23-36. 